\title{
Ectopic expression of cyclin D1 impairs the proliferation and enhances the apoptosis of a murine lymphoid cell line
}

\author{
F Duquesne ${ }^{1}$, M Florent ${ }^{1}$, G Roué $^{1}, \mathrm{X}$ Troussard $^{2}$ and \\ B Sola ${ }^{\star, 1}$ \\ 1 Université de Caen, UPRES-EA 2128, UFR de Médecine, CHU Côte de Nacre, \\ 14032 Caen Cedex, France \\ 2 Laboratoire d'Hématologie, CHU Côte de Nacre, 14033 Caen Cedex, France \\ * Corresponding author: B Sola, Université de Caen, UPRES-EA 2128, UFR de \\ Médecine, CHU Côte de Nacre, 14032 Caen Cedex, France \\ Tel:+33 2310682 25; Fax:+33 2314740 84; \\ E-mail: sola@medecine.unicaen.fr
}

Received 22.12.99; revised 9.8.00; accepted 7.9.00

Edited by M Piacentini

\begin{abstract}
Cyclin D1, a key regulator of the cell cycle, acts as an oncogene when over-expressed in several types of cancer. In some Bchronic lymphoproliferative disorders, the over-expression of cyclin D1 protein is thought to confer a proliferative phenotype. We have generated BaF3 pro-B cell derivatives in which cyclin D1 can be induced rapidly and reversibly in a dose-dependent manner by the hormone muristerone $A$. When non-expressing clones displayed the same proliferative capacity as the parental cell line, in the sub-clones, a moderate induction of cyclin D1 lengthened the proliferation rate. The over-expression of cyclin D1 had the same effects on cell proliferation but also led ultimately to cell death by apoptosis. The induction of cyclin D1 in growth factor-deprived cells as well as in anticancer drug-treated cells also reinforced the magnitude of apoptosis. Thus, the expression of cyclin D1 in lymphoid cells does not confer a proliferative advantage but rather alters the response of cells towards apoptotic stimuli in a p53-independent manner.Cell Death and Differentiation (2001) $8,51-62$.
\end{abstract}

Keywords: cyclin; lymphocyte; cell cycle; apoptosis; kinase; retinoblastoma protein

Abbreviations: IL-3, interleukin-3; pRb, retinoblastoma protein; CDK, cyclin-dependent kinase

\section{Introduction}

Cell proliferation is initiated by extracellular signals that activate a cascade of events which ultimately lead to cell growth and division. Progression through cell cycle is controlled by regulatory proteins, the cyclins, and their catalytic partners, the cyclin-dependent kinases (CDKs), which are sequentially and specifically recruited. ${ }^{1}$ Phosphorylation of the retinoblastoma protein (pRB) by cyclins $D$ associated with CDK4 or CDK6 triggers the onset of S-phase by inducing the release of E2F transcription factors from growth inhibitory $\mathrm{pRb}$ complexes. ${ }^{2,3}$ Members of cyclin D family share sequence homologies ${ }^{4}$ and functional properties but display a tissue-restricted expression indicating that they could possess an unique role either in the regulation of cell proliferation or in other key steps of the cell's fate. Cyclin D1 is induced in response to mitogenic signals and controls the progression through the $\mathrm{G} 1$ phase and the transition from $\mathrm{G} 1$ to S-phase. Over-expression of cyclin D1 has been shown to play a critical role in tumour formation. Indeed, cyclin D1 is amplified and over-expressed in a significant fraction of breast and squamous cell carcinomas, ${ }^{5-8}$ parathyroid adenomas ${ }^{9}$ and in oesophageal carcinomas. ${ }^{10,11}$ Over-expression of cyclin D1 in mammary cells of transgenic mice results in abnormal cellular proliferation and in development of mammary adenocarcinomas. ${ }^{12}$ In contrast, lymphocytes of mice transgenic for the cyclin D1 gene driven by an immunoglobulin enhancer, do not exhibit any increase of proliferation rate or any change in growth properties. ${ }^{13}$ Thus, the constitutive expression of cyclin D1 in lymphocytes does not contribute to the development of T- or B-malignancies in transgenic animals. In vitro, different paradigms of cyclin D1 over-expression have been explored in order to determine whether cyclin D1 is oncogenic. Clearly, depending on the paradigms, the results are conflicting. For example, in established fibroblastic cell lines or in embryonic fibroblasts, over-expression of cyclin D1 accelerates transit through G1 and enhances cell proliferation and cell transformation. ${ }^{14-16}$ In a breast tumour cell line, over-expression of cyclin D1 results in continuous proliferation even in low-serum condition. ${ }^{17}$ In contrast, in several mammary epithelial cell lines, increased expression of cyclin D1 inhibits growth, induces differentiation and enhances apoptosis triggered by growth factor deprivation. ${ }^{18,19}$ Thus, a moderate up-regulated expression of cyclin D1 can enhance cell growth but a high level can have an inhibitory effect even in the same cell type. Alternatively, the effects of increased expression of cyclin D1 may be highly dependent on either the cell type or the level of expression of other genes involved in the regulation of cell cycle progression or DNA synthesis.

Peripheral blood lymphocytes never express cyclin D1;20 indeed, in the B-lymphoid lineage, cyclin D1 expression is always associated with a proliferative tumoral phenotype. Some B-lymphoma cell lines ${ }^{21}$ or B-cells of patients suffering from chronic lymphoproliferative disorders such as mantle cell lymphoma (MCL), ${ }^{22,23}$ or atypical B-cell chronic lymphoid leukaemia (B-CLL), ${ }^{24}$ display high levels of cyclin D1 mRNA and protein. In these haemopathies, in most cases, the chromosomal translocation $t(11 ; 14)(q 13 ; q 32)$ results in rearrangement of the CCND1 locus and in activation of cyclin D1 gene transcription driven by regulatory sequences of the $\mathrm{IgH}$ locus. The hypothesis that has gained general acceptance is that the over-expression of a normal cyclin D1 protein in 
lymphocytes leads to an abnormal proliferation phenotype. To our knowledge, the effects of induction of cyclin D1 in lymphoid cells have not been reported and this study is particularly relevant considering the physiopathology of cyclin D1-expressing haematopoietic malignancies. To further explore the role(s) of cyclin D1, we have generated pro-B lymphoid cell clones expressing cyclin D1 protein in an inducible and transient manner. The establishment of these cyclin D1-expressing B-lymphocytes allowed us to study the effects of cyclin D1 protein induction and overexpression. We provide evidence that cyclin D1 acts as an inhibitor of cell proliferation in BaF3 lymphoid cells and enhances apoptosis after growth factor deprivation or anticancer drug treatment. Furthermore, the apoptotic pathway elicited by cyclin D1 induction does not involve the p53 transduction cascade.

\section{Results}

\section{Regulation of cyclin D1 by muristerone A in BaF3 sub-clones}

The interleukin-3-(IL-3)-dependent murine pro-B BaF3 cell line ${ }^{25}$ was chosen because it does not express cyclin D1 and is a useful model for the study of cell proliferation and apoptosis regulation after IL-3 withdrawal. Previous attempts to construct stable BaF3 cells constitutively over-expressing cyclin D1 driven by the CMV promoter failed (data not shown). To avoid potential toxic effects of constitutive cyclin D1 overexpression and to have a more versatile system, we employed an ecdysone inducible-derived expression vector. ${ }^{26}$ After transfection by electroporation of successively, the regulatory plasmid pVgRXR, then the expression plasmid pIND-D1 containing the complete cDNA of human cyclin D1, ${ }^{9}$ and after cloning by limiting dilution in culture medium supplemented with the appropriate antibiotics, three resistant clones potentially expressing cyclin D1 were selected. BaF3 parental cells as well as BD1-9, BD1-31 and BD1-A21 subclones were harvested for total proteins after treatment with different concentrations of hormone and analyzed $24 \mathrm{~h}$ later for cyclin D1 expression. Results are reported in Figure 1. No endogenous cyclin D1 protein was detected in BaF3 cells or in unstimulated BD1-9 cells. In contrast, a basal amount of cyclin D1 protein was present in untreated BD1-31 and BD1-A21. When cyclin D1 level was unchanged after muristerone $A$ treatment in BD1-A21 even with high doses (Figure 1), the cyclin D1 level was strictly dependent on the concentration of

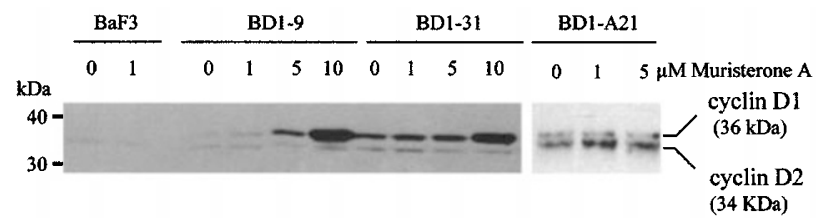

Figure 1 Expression of cyclin D1 in BaF3-derived clones analysed by Western blot. Cyclin D1 protein (36 kDa) was analyzed in BD1-9, BD1-31, $\mathrm{BD} 1-\mathrm{A} 21$ sub-clones as well as in BaF3 parental cells incubated $24 \mathrm{~h}$ in the absence or the presence of muristerone $\mathrm{A}(1-10 \mu \mathrm{M})$. Fifty $\mu \mathrm{g}$ of total proteins were separated in $12 \%$ SDS-PAGE, transferred on Immobilon membranes and incubated with an anti-cyclin D1 polyclonal antibody hormone in the BD1-9 and BD1-31 sub-clones. A faint band, likely corresponding to cyclin D2 (34 kDa) was detected in some circumstances with the anti-cyclin D1 antibody; the intensity of this band did not vary in the different samples tested. The kinetics of cyclin D1 synthesis and degradation was then analyzed (Figure 2A). We observed that the maximal level of cyclin D1 was reached $6 \mathrm{~h}$ after induction by muristerone A, in both BD1-9 and BD1-31 cells. At $24 \mathrm{~h}$, the level of cyclin D1 was decreasing. At $96 \mathrm{~h}$, no cyclin D1 was detected for the lower concentration of hormone $(1 \mu \mathrm{M})$ and the level of cyclin D1 was substantially reduced for the higher dose $(5 \mu \mathrm{M})$. To determine whether the rapid turnover of cyclin D1 was controlled by the ubiquitin/proteasome physiological pathway, ${ }^{27}$ cyclin D1-expressing BD1-9 and BD1-31 cells were treated with LLnL ( $\mathrm{N}$-acetyl-leucinyl-leucinyl-norleucinal), a peptide aldehyde that prevents protein degradation by inhibiting the $26 \mathrm{~S}$ proteasome. As compared to non-treated cells, LLnL treatment resulted in the partial prevention of cyclin D1 degradation in both cell clones (Figure 2B). Our results indicate that the physiological pathway of cell cycle protein degradation is functional in the BD1 sub-clones and that cyclin D1 can be degraded by this pathway.

\section{Effects of cyclin D1 expression on cell proliferation and cell viability}

BaF3 and BD1 sub-clones were seeded at low density $\left(5 \times 10^{3} \mathrm{cell} / \mathrm{ml}\right)$ and cultured for 1 week. Cells were refed every 2 days and counted every day during this period. BD1 sub-clones displayed proliferation curves (Figure 3A) and doubling times (ranging from 19-23 h, Table 1) equivalent to those of BaF3 cells (doubling time: $21 \mathrm{~h}$ ), indicating that the integration of cyclin D1 expression plasmid had no or little
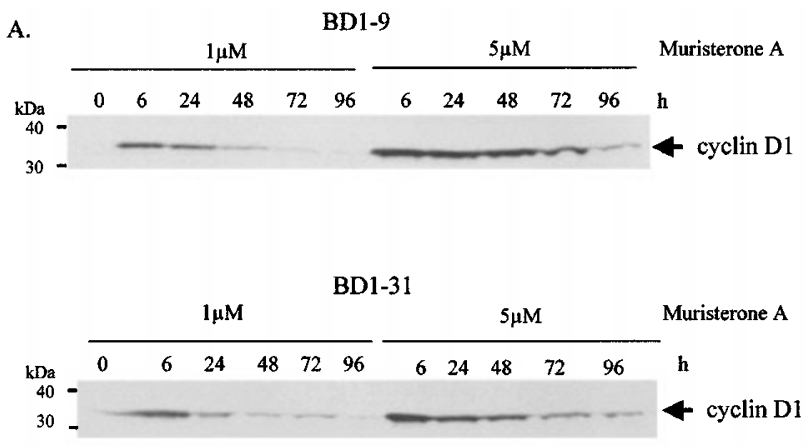

B.
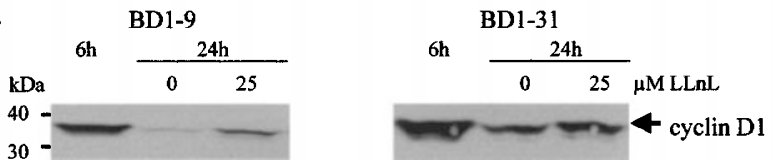

Figure 2 Kinetics of cyclin D1 synthesis and degradation in BD1-9 and BD131 sub-clones. (A) BD1-9 and BD1-31 cells were incubated for the indicated periods $(6-96 \mathrm{~h})$ in absence or in presence of muristerone $A(1-5 \mu \mathrm{M})$ added once at the beginning of the culture. (B) Cells were seeded at $5 \times 10^{5}$ cells $/ \mathrm{ml}$ in medium containing $1 \mu \mathrm{M}$ muristerone $\mathrm{A}$. Six $\mathrm{h}$ later, cells were treated (or not) with $25 \mu \mathrm{M}$ LLnL for a $18 \mathrm{~h}$-period then harvested. Cyclin D1 expression was analyzed as described in the legend to Figure 1 
effect on cell proliferation properties. The same experiment was realised with cells seeded at a higher density $\left(5 \times 10^{4}\right.$ cell $/ \mathrm{ml}$ ) and gave similar results (data not shown). The basal level of cyclin D1 protein present in BD1-31 and BD1-A21 had no major effect on proliferation rate, even if both clones seemed to proliferate more quickly. When cyclin D1 was induced in the responding clones BD1-9 and BD1-31, we observed a clear slowing down of cell proliferation in strict

A. $\rightarrow$ BaF.3 $\leftarrow$ BD1-31

$\rightarrow-\mathrm{BD} 1-9 \rightarrow \mathrm{BD} 1-\mathrm{A} 21$

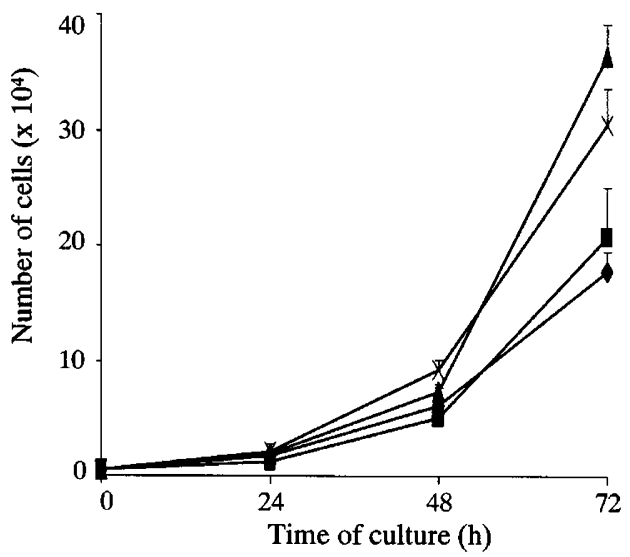

B.

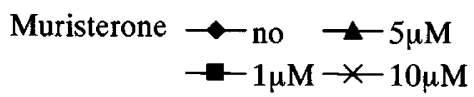

BD1-9
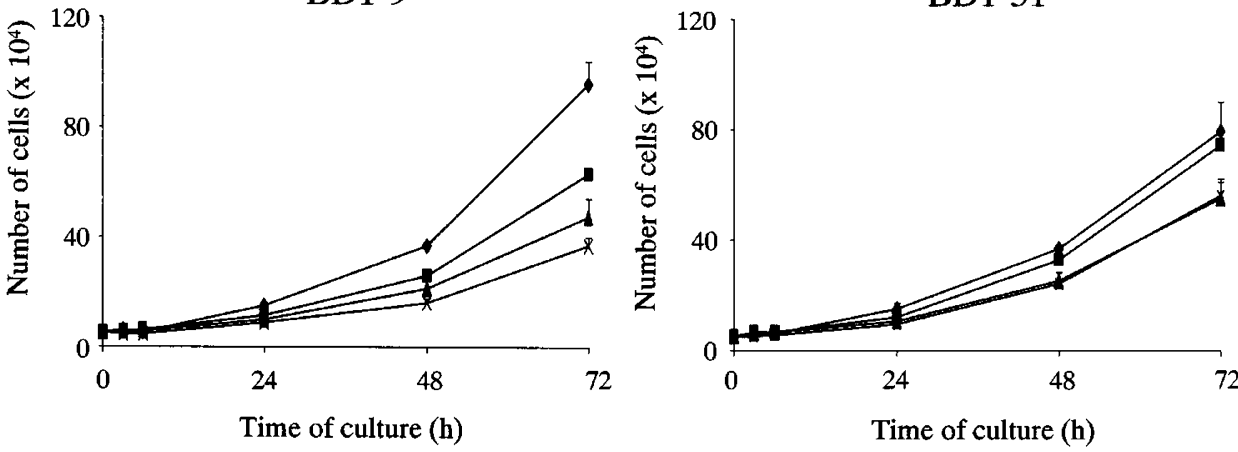

C.

Muristerone $\multimap$ no
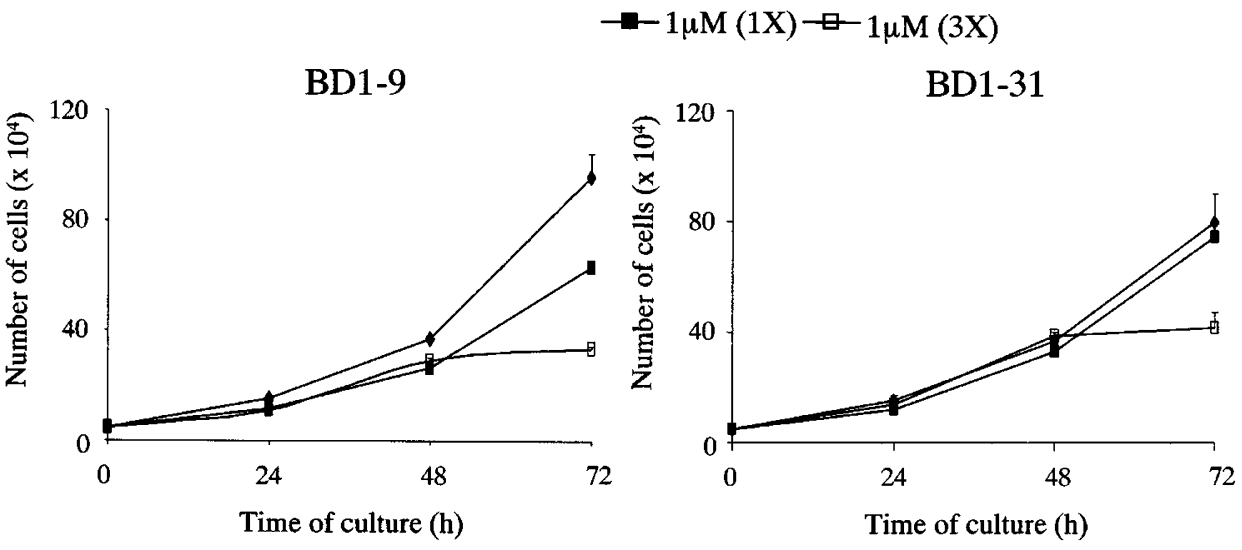

Figure 3 Proliferation curves of BaF3 and derivatives. (A) BaF3, BD1-9, BD1-31 and BD1-A21 cells were seeded at $5 \times 10^{3}$ cells/ml and cultured in complete medium for the indicated period. Number of cells was determined after Trypan blue exclusion in a haemocytometer. Error bars represent the SD of three independent experiments. (B) BD1-9 and BD1-31 cells were seeded at $5 \times 10^{4}$ cells $/ \mathrm{ml}$ without or with different concentrations of muristerone A (1-10 $\left.\mu \mathrm{M}\right)$ Number of viable cells was recorded as in $\mathbf{A}$. Mean and SD from three independent experiments were noted on the graph. (C) BD1-9 and BD1-31 cells were seeded as in $\mathbf{A}$ and treated with $1 \mu \mathrm{M}$ muristerone $\mathbf{A}$ three times at day 0,1 and 2. Number of cells was evaluated and represented as before 
correlation with the dose of muristerone A, i.e. of cyclin D1 protein level (Figure 3B). As reported in Table 1, during the first $24 \mathrm{~h}$ after hormone treatment, induction of cyclin D1 dramatically increased the doubling times of BD1-9 and BD131 sub-clones. This increase in doubling time was also strictly a function of the dose of muristerone A, i.e. of the cyclin D1 level. However, the block of cell proliferation was transient. At $48 \mathrm{~h}$ after muristerone A treatment, and depending on the

Table 1 Doubling time of BaF3 cells and derivatives

\begin{tabular}{lcc}
\hline & $\begin{array}{c}\text { Muristerone A } \\
(\mu \mathbf{M})\end{array}$ & $\begin{array}{c}\text { Doubling time } \\
(\mathbf{h})\end{array}$ \\
\hline BaF3 & 0 & 21 \\
BD1-9 & 0 & 23 \\
& 1 & 27 \\
BD1-31 & 5 & 29 \\
& 10 & 41 \\
& 0 & 20 \\
BD1-A21 & 1 & 30 \\
& 5 & 33 \\
\end{tabular}

Cells were plated at $5 \times 10^{4}$ cells $/ \mathrm{ml}$ in complete medium. Doubling times were determined as described in Materials and Methods during the first $24 \mathrm{~h}$ of the culture various hormone concentrations, we observed the recovery of proliferation rate as represented by the slopes of the curves. In order to confirm that the block of cell proliferation was reversible, i.e. was strictly dependent on cyclin D1 level, we repeated the experiment but added the lower dose of muristerone $\mathrm{A}(1 \mu \mathrm{M})$ every day for 3 days to maintain the expression of cyclin D1 (as verified by Western blot, data not shown). As indicated in Figure 3C, BD1-9 and BD1-31 cells stopped to proliferate $48 \mathrm{~h}$ after the beginning of the culture. The treatment of responding clones with muristerone $A$ induced no deleterious effect for low dose of muristerone $A$ $(1 \mu \mathrm{M})$ but a clear increase of cell mortality for the highest doses of muristerone A during the first $24 \mathrm{~h}$ of treatment (Figure 4A). This effect was enhanced during the next $24 \mathrm{~h}$ before the complete cyclin D1 degradation that occurred later. The cell mortality was still increased for BD1-31 cells but was almost stable thereafter for BD1-9 cells, probably reflecting the degradation of cyclin D1. We never observed any cell mortality (or, in contrast, any cell proliferation triggering) when BaF3 (Figure 4A) or BD1-A21 (data not shown) cells were cultured even in the presence of high doses of muristerone $A$, indicating that muristerone $A$ had no effect per se. The percentage of dead BaF3 cells was comprised between 2 and $8 \%$ depending on muristerone $A$ concentrations and on the time of treatment (Figure 4A). We rather concluded that over-
A

BaF3

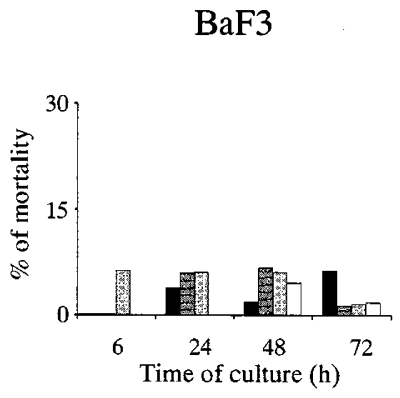

B.

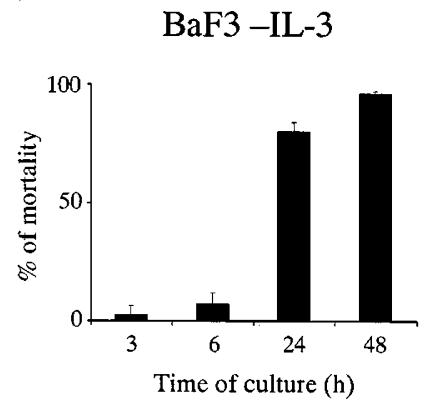

Muristerone no 固 $5 \mu \mathrm{M}$

$\therefore \mu \mathrm{M} \square 10 \mu \mathrm{M}$

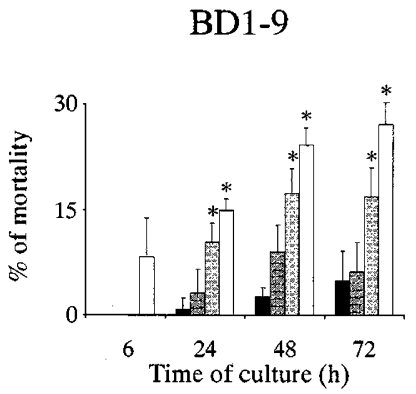

BD1-31
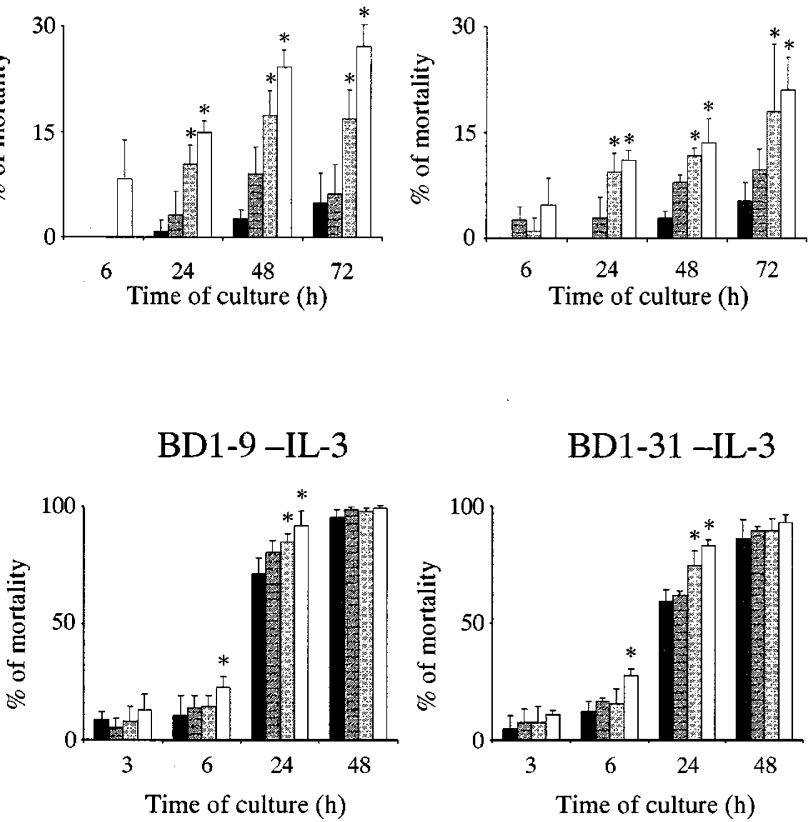

Figure 4 Effect of cyclin D1 expression and IL-3 deprivation on cell mortality of BaF3, BD1-9 and BD1-31 derivatives. (A) BaF3, BD1-9 and BD1-31 cells were seeded at a density of $5 \times 10^{4} \mathrm{cell} / \mathrm{sl}$ in complete medium in the absence or in the presence of muristerone $\mathrm{A}$ at different concentrations $(1,5$ and $10 \mu \mathrm{M})$. Cells from triplicate wells were counted after Trypan blue exclusion at the indicated times $(3,6,24,48$ and $72 \mathrm{~h})$. Error bars represent SD of three independent experiments. ${ }^{*} P<0.01$ indicates significant difference between control non treated cells and muristerone A-treated cells with the Student $t$-test. (B) BaF3, BD1-9 and BD1-31 cells were seeded at $5 \times 10^{4}$ cells $/ \mathrm{ml}$ in medium containing no WEHI-3B CM and treated (or not) with $1-10 \mu \mathrm{M}$ muristerone A. Cell mortality was determined as before and mean and SD determination from 3 independent experiments. ${ }^{*} P<0.01$ with the Student $t$-test 
expression of cyclin D1 induced death of lymphoid cells. Our results indicate that ectopic expression of cyclin D1 in asynchronously growing $\mathrm{BaF} 3$ cells greatly alters their proliferation properties, while a moderate over-expression of cyclin D1 has no cytotoxic effect and leads to a slowing down of cell proliferation, a high level of cyclin D1 have the same effect on proliferation rate and induces cell death.

\section{Effect of cyclin D1 induction on cell cycle parameters}

Considering the alteration induced by cyclin D1 in expressing cells, we further investigated whether it changed the distribution of cell cycle phases. BD1-9 and BD1-31 cells were treated with $1 \mu \mathrm{M}$ muristerone $\mathrm{A}$ (non-toxic dose) for $24 \mathrm{~h}$ and analyzed by FACS after propidium iodide incorporation. Representative flow cytometric profiles for BaF3, BD1-9, and cyclin D1-expressing BD1-9 cell lines are shown in Figure 5 (left part of the figure). Data obtained with the whole series are reported in Table 2. Compared to nonexpressing clones, cyclin D1 induction in BD1-9 and BD1-31 cells had no effect on the distribution of cells in G0/G1, S- and G2/M-phases. We calculated the approximate duration of each cell cycle phase for each cell line and each culture condition, considering the determined doubling times (Table 1). Results are reported in Table 3. The duration of cell cycle
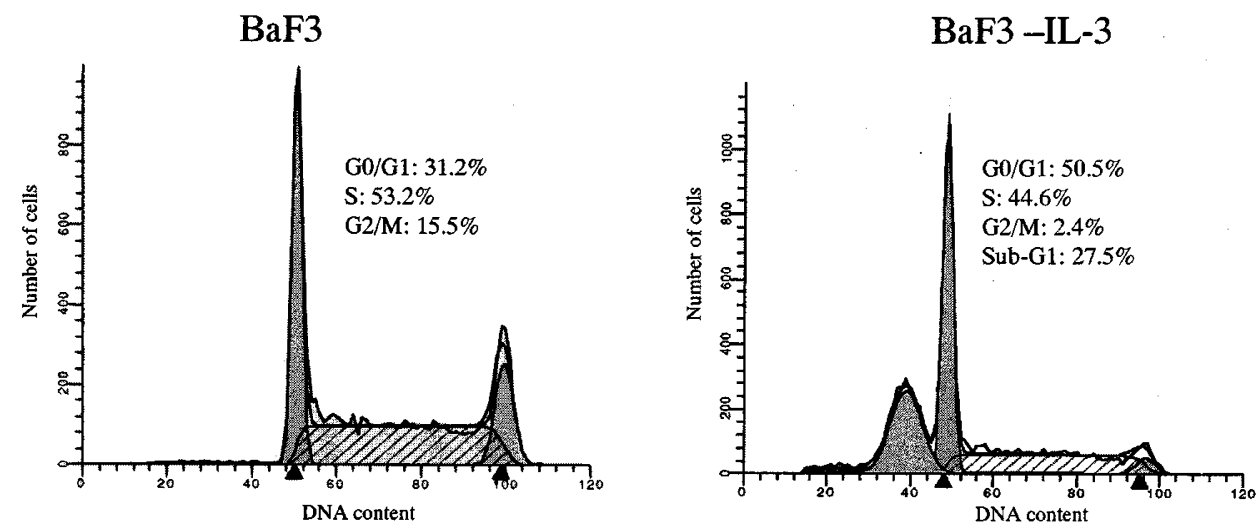

BD1-9
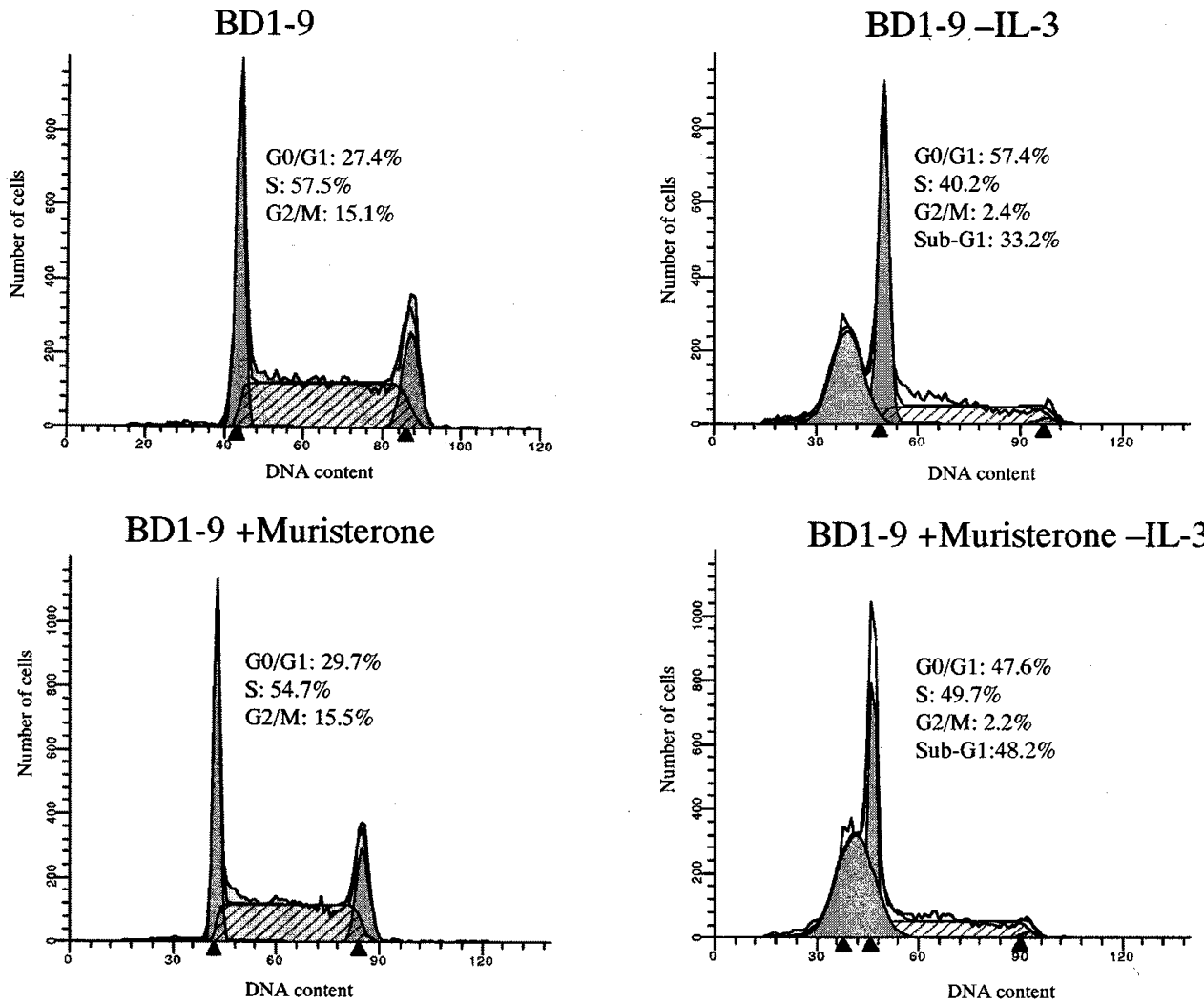

Figure 5 Cell cycle distribution of BaF3 and BD1-9 cells submitted to different culture conditions. BaF3 and BD1-9 cells were cultured in complete medium, then they were (or not) deprived in IL-3 for $14 \mathrm{~h}$ and BD1-9 cells were treated (or not) with $1 \mu \mathrm{M}$ muristerone A for $24 \mathrm{~h}$. After these treatments, cells were stained with propidium iodide and analyzed with a FACScalibur. The percentage of cells within each cell cycle phase and cells having a sub-content of DNA is indicated on the figure 
phases of BaF3 and BaF3-derived non-treated cells were almost identical. In contrast, after induction of cyclin D1 by muristerone A treatment, in BD1-9 and BD1-31 cells, the duration of all cell cycle phases was dramatically increased. Thus, the increase in doubling times of cyclin D1-expressing cells (BD1-9 and BD1-31 cells) is due to a lengthening of G0/ G1, S- and G2/M-phase duration.

\section{Effect of cyclin D1 expression in IL-3 deprived BD1-subclones}

When BaF3 cells were deprived of IL-3 by washes and cultured in medium without WEHI-3B conditioned medium (CM) as source of IL-3, there was a rapid decline in cell viability beginning at $6 \mathrm{~h}$ that led to more than $95 \%$ cell death in $48 \mathrm{~h}$ (Figure 4B). This cell death phenotype was characterised as apoptotic by several groups including us. ${ }^{28}$ BD1 sub-clones were cultured in the absence of IL-3, treated (or not) with different concentrations of muristerone A (1$10 \mu \mathrm{M})$ and harvested at different time intervals. BD1-9 and BD1-31 sub-clones displayed the same sensitivity upon IL-3 withdrawal as BaF3 parental cells (Figure 4B). The induction of cyclin D1 in BD1-9 and BD1-31 cells enhanced the effects of IL-3 withdrawal on cell apoptosis. Indeed, cell mortality of cyclin D1-expressing clones was accelerated as a function of muristerone A concentration i.e. of cyclin D1 protein level (see $10 \mu \mathrm{M}$ muristerone $\mathrm{A}$ at $6 \mathrm{~h}, 5$ and $10 \mu \mathrm{M}$ at $24 \mathrm{~h}$ for both clones).

\section{Cyclin D1-induced cell death is apoptotic}

In order to characterise the synergistic effect of IL-3 deprivation and cyclin D1 over-expression, BaF3 cells and derivatives were seeded after washes, in absence of any source of IL-3 and treated or not with muristerone $\mathrm{A}(1 \mu \mathrm{M})$. Cells were analyzed $14 \mathrm{~h}$ later, by flow cytometry after DNA staining with propidium iodide. As exemplified in Figure 5 (right side of the figure), IL-3 withdrawal from BaF3 and BD1-9 cells led to the appearance of a sub-G1 peak corresponding to apoptotic cells possessing a sub-DNA content. After induction of cyclin D1 in deprived BD1-9 cells, the percentage of apoptotic cells present in the sub-G1 peak was markedly enhanced (48.2 versus $33.2 \%$ of apoptotic cells) confirming that cyclin D1 over-expression resulted in an increase in

Table 2 Percentage of cells within the different phases of the cell cycle

\begin{tabular}{lcccc}
\hline Cells & $\begin{array}{c}\text { Muristerone A } \\
(\mu \mathbf{M})\end{array}$ & $\begin{array}{c}\text { G0/G1 } \\
\mathbf{( \% )}\end{array}$ & $\mathbf{S}(\%)$ & $\begin{array}{c}\text { G2/M } \\
\mathbf{( \% )}\end{array}$ \\
\hline BaF3 & 0 & $32.2 \pm 2.3$ & $53.9 \pm 1.1$ & $13.9 \pm 1.6$ \\
BD1-9 & 0 & $29.3 \pm 2.2$ & $57.9 \pm 0.3$ & $12.9 \pm 2.4$ \\
& 1 & $30.6 \pm 2.4$ & $55.0 \pm 0.9$ & $14.4 \pm 1.7$ \\
BD1-31 & 0 & $28.9 \pm 0.7$ & $51.7 \pm 0.6$ & $19.4 \pm 0.1$ \\
& 1 & $30.1 \pm 0.5$ & $50.8 \pm 0.4$ & $19.2 \pm 0.5$ \\
BD1-A21 & 0 & $32.8 \pm 0.7$ & $53.6 \pm 0.3$ & $13.6 \pm 0.8$ \\
\hline
\end{tabular}

Cells were plated at $5 \times 10^{4}$ cells $/ \mathrm{ml}$, grown for $24 \mathrm{~h}$ without or with muristerone A $(1 \mu \mathrm{M})$ final concentration), labelled with propidium iodide and analyzed by FACS as described in Materials and Methods. Values are the mean and the standard deviation (SD) of three independent experiments sensitivity towards apoptosis. The same result was obtained for BD1-31 cells (data not shown). We also verified the type of cell death induced by high doses of muristerone A in BD1-9 and BD1-31 cells. As depicted in Table 4, when BD1-9 and BD1-31 cells were treated with $5 \mu \mathrm{M}$ muristerone $\mathrm{A}$, they ceased proliferation (the number of cells in S-phase was diminished) and were blocked in G0/G1 phase (the number of cells in G0/G1 phase was increased). Moreover, the enforced expression of cyclin D1 by $5 \mu \mathrm{M}$ muristerone $\mathrm{A}$, led to the appearance of a cell population possessing a sub-DNA content reminiscent of apoptotic cells. The characterisation of

Table 3 Duration of cell cycle phases in cells expressing or not cyclin D1

\begin{tabular}{lcccc}
\hline Cells & $\begin{array}{c}\text { Muristerone A } \\
(\mu \mathbf{M})\end{array}$ & $\begin{array}{c}\text { G0/G1 } \\
(\mathbf{h})\end{array}$ & $\mathbf{S}$ (h) & $\begin{array}{c}\text { G2/M } \\
(\mathbf{h})\end{array}$ \\
\hline BaF3 & 0 & 6.8 & 11.3 & 2.9 \\
BD1-9 & 0 & 6.8 & 13.3 & 2.9 \\
& 1 & 8.3 & 14.8 & 3.9 \\
BD1-31 & 0 & 5.8 & 10.3 & 3.9 \\
& 1 & 9.0 & 15.2 & 5.8 \\
BD1-A21 & 0 & 6.2 & 10.2 & 2.6 \\
\hline
\end{tabular}

Values were calculated from the doubling time of each indiciated cell line cultured without or with $1 \mu \mathrm{M}$ muristerone $\mathrm{A}$ and the percentage of total cell population in the indicated phase of the cell cycle (see Tables 1 and 2)

Table 4 Distribution of cells within cell cycle phase after over-inducation of cyclin D1

\begin{tabular}{lccccc}
\hline Cells & $\begin{array}{c}\text { Muristerone } \\
\mathbf{A}(\mu \mathbf{M})\end{array}$ & $\begin{array}{c}\text { G0/G1 } \\
\text { (\%) }\end{array}$ & S (\%) & \multicolumn{1}{c}{$\begin{array}{c}\text { G2/M } \\
\text { (\%) }\end{array}$} & $\begin{array}{c}\text { pre-G1 } \\
\text { (\%) }\end{array}$ \\
\hline BD1-9 & 0 & $36.5 \pm 0.5$ & $53.8 \pm 0.9$ & $9.6 \pm 0.7$ & $0.0 \pm 0.0$ \\
& 5 & $45.1 \pm 0.4$ & $45.5 \pm 0.1$ & $9.4 \pm 0.5$ & $7.3 \pm 0.5$ \\
BD1-31 & 0 & $36.1 \pm 0.9$ & $53.0 \pm 0.9$ & $11.0 \pm 0.2$ & $0.0 \pm 0.0$ \\
& 5 & $44.2 \pm 1.4$ & $42.9 \pm 1.8$ & $13.0 \pm 0.8$ & $5.8 \pm 2.6$ \\
\hline
\end{tabular}

Cells were plated at $5 \times 10^{4}$ cells $/ \mathrm{ml}$, grown for $24 \mathrm{~h}$ without or with $5 \mu \mathrm{M}$ muristerone A, labelled with propidium iodide and analyzed by FACS. Values are the mean and the SD of three independent experiments
BD1-31 non treated

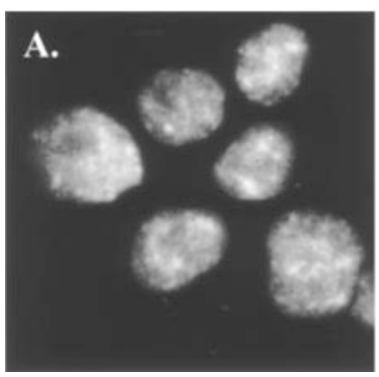

BD1-31 + Muristerone

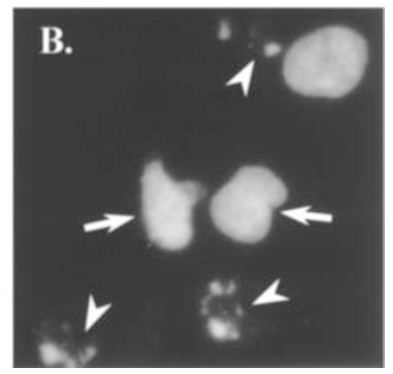

Figure 6 DAPI-staining of BaF3 cells derivatives after cyclin D1 induction. DAPI staining of non treated (A) or BD1-31 cells incubated with $5 \mu \mathrm{M}$ muristerone A for $48 \mathrm{~h}$. (B) Normal cells (arrows), apoptotic cells with condensed chromatin (arrows, B) and apoptotic bodies (arrowheads, B) are recognised. Magnification, $\times 400$ 
cyclin D1-expressing cells as apoptotic was also confirmed after morphological microscopic examination of DAPI-stained cells. As exemplified in Figure 6, normal cells (A) and cells with shrunken cellular bodies and apoptotic profiles (B) were recognised. We thus concluded that a sustained overexpression of cyclin D1 triggered apoptosis in growing cells and enhanced apoptosis induced by growth factor deprivation.

\section{Sensitisation of cyclin D1-expressing cells to etoposide-induced apoptosis}

We then asked whether induction of cyclin D1 could also enhance apoptosis induced by another type of stimulus. We chose etoposide, an anticancer drug, which inhibits topoisomerase II, induces DNA double-strand breaks and a rapid apoptotic cell death. Dose-response studies were performed
BaF3

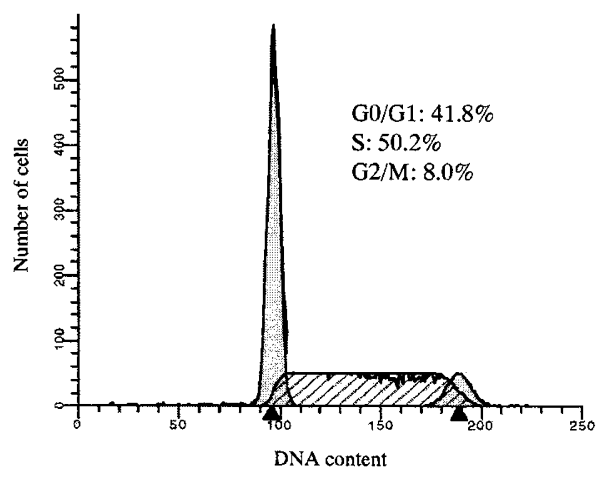

BD1-9

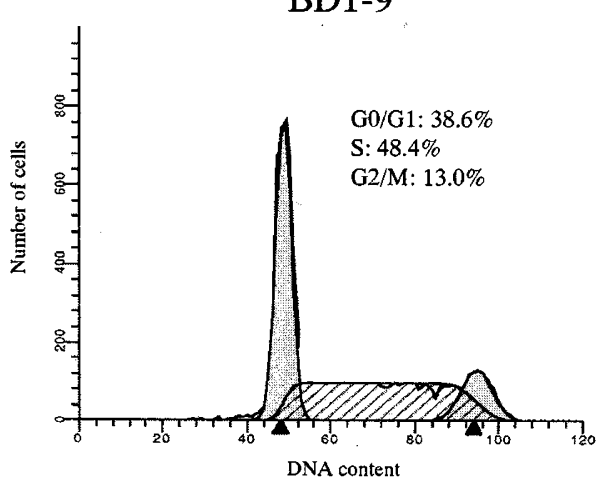

BD1-9 + Muristerone

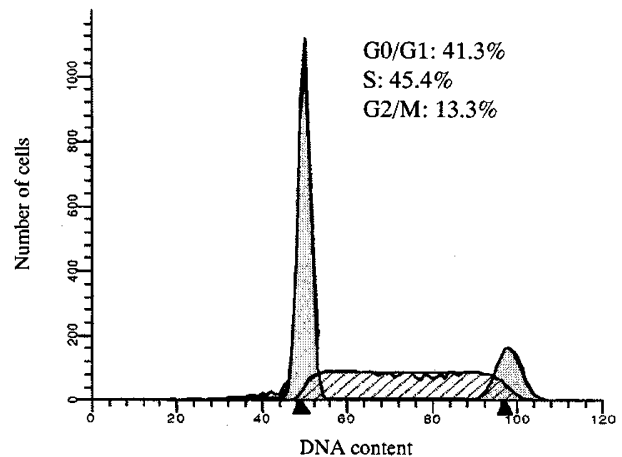

$\mathrm{BaF} 3+$ Etoposide

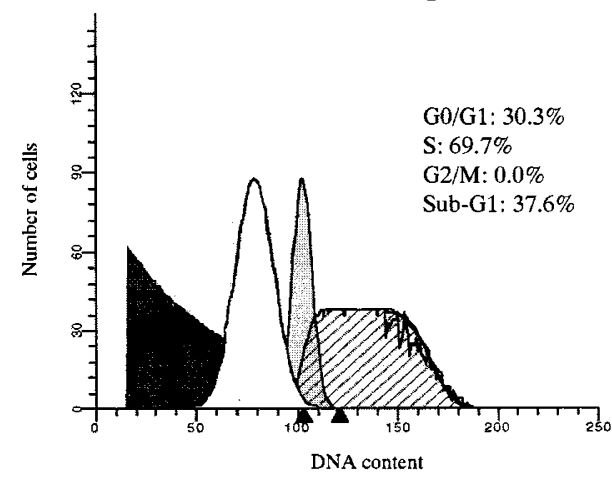

BD1-9 + Etoposide

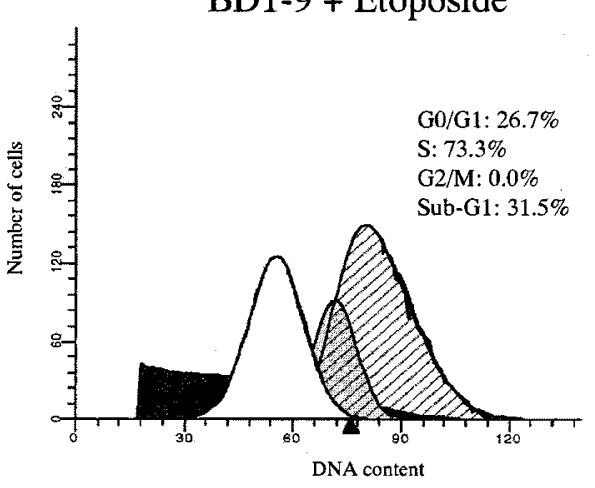

BD1-9 + Muristerone +Etoposide

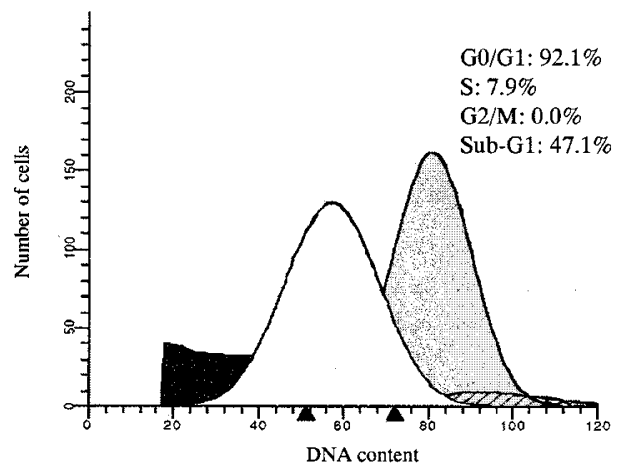

Figure 7 Cell cycle distribution of BaF3, BD1-9 and BD1-31 expressing cyclin D1 after etoposide treatment. BaF3 and BD1-9 cells were cultured in complete medium (control) or medium containing $40 \mu \mathrm{g} / \mathrm{ml}$ etoposide for $24 \mathrm{~h}$. BD $1-9$ cells, muristerone $\mathrm{A}(1 \mu \mathrm{M})$ was added or not (control) at the same time. Cells were then processed and analyzed as described in Figure 5 
on $\mathrm{BaF} 3$ cells and derivatives with various concentrations of etoposide. As determined after Trypan blue exclusion, treatment with $40 \mu \mathrm{g} / \mathrm{ml}$ etoposide resulted in a cell mortality of $78 \%$ for $\mathrm{BaF} 3,72 \%$ for BD1-9 and $88 \%$ for BD1-A21 at $24 \mathrm{~h}$ (data not shown). BaF3 cells, BD1-9 and BD1-31 cells induced or not for cyclin D1 expression with $1 \mu \mathrm{M}$ muristerone A were treated with $40 \mu \mathrm{g} / \mathrm{ml}$ etoposide and analyzed for the presence of cells having sub-diploid DNA content $24 \mathrm{~h}$ later. After drug treatment BaF3 cells and derivatives exhibited a block in S-phase. As deduced from FACS analysis of BaF3 and BD1-9 cells (Figure 7), the cell population in G0/G1 phase was decreased (41.8 versus $30.3 \%$ and 38.6 versus $26.7 \%$, respectively). There was a complete absence of dividing cells (no cells in G2/M-phase) and an increase of the cell population in S-phase (50.2 versus $69.7 \%$ and 48.4 versus $73.3 \%$, respectively). Moreover, etoposide induced cell apoptosis since $37.6 \%$ BaF3 and $31.5 \%$ BD1 cells displayed a sub-diploid DNA content. The induction of cyclin D1 with $1 \mu \mathrm{M}$ muristerone $\mathrm{A}$ in BD1-9 cells potentiated the effects of etoposide on cell apoptosis. Indeed, the percentage of cells having a sub-diploid DNA content increased from 31.5 to $47.1 \%$ in BD1-9 cells. Similar results

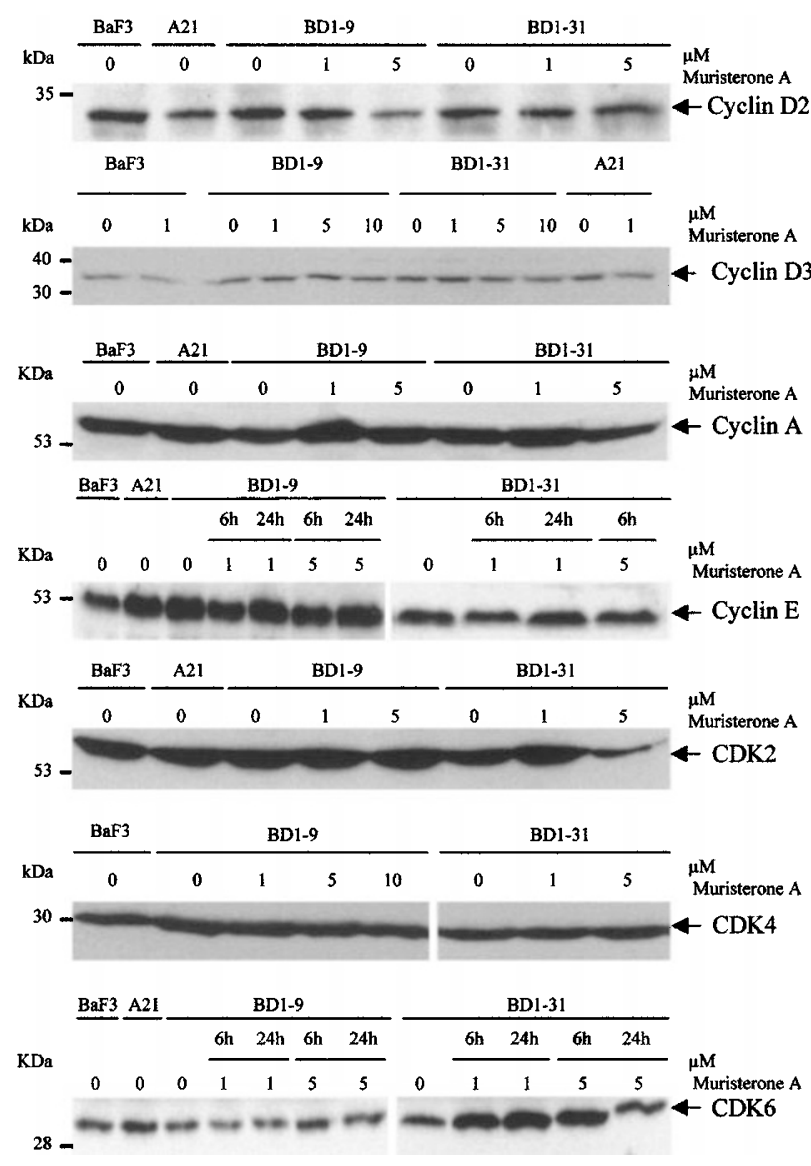

Figure 8 Western blot analysis of the cell cycle partners of cyclin D1. Whole cell extracts were prepared from cells non treated or treated with the indicated concentrations of muristerone A harvested $24 \mathrm{~h}$ after the treatment. Proteins $(50 \mu \mathrm{g})$ were separated on SDS-PAGE $(12 \%)$, transferred onto PVDF membranes and immunoblotted with the corresponding antibodies. A21 are BD1-A21 cells were obtained with BD1-31 cells (data not shown). We conclude that induction of cyclin D1 in lymphoid cells modifies their response towards diverse apoptotic stimuli such as lack of survival signal (growth factor withdrawal) and DNA damage (anticancer drug).

\section{Analysis of G1 phase-related proteins in cyclin D1-expressing lymphoid cells}

As reported Figure 8, cyclin D1 induction had no effect on levels of cyclin D2, cyclin D3, CDK4, CDK6 or on levels of cyclin $A$, cyclin $E$ and $C D K 2$, all involved in regulation of $\mathrm{G} 1$ phase progression and in G1 to S-phase transition. We next investigated the effect of cyclin D1 expression on the phosphorylation status of $\mathrm{pRb}$ and related pocket proteins p107 and p130. On immunoblots, highly phosphorylated protein species migrated more slowly than hypophosphorylated forms. In BaF3, in BD1-A21 and in non-treated BD1-9 and BD1-31 cells, pRb appeared as several species likely corresponding to several phosphorylation degrees (Figure 9A, lanes 1-3 and 8). Induction of cyclin D1 in BD1-9 and BD1-31 cells led to a shift in the $\mathrm{pRb}$ migration corresponding to the appearance of hyperphosphorylated $\mathrm{pRb}$ forms (Figure $9 A$, lanes 4, 6, 9 and 11). Hyperphosphorylated forms of $p R b$ were present as long as cyclin D1 was present (24 h after stimulation with $5 \mu \mathrm{M}$ muristerone $\mathrm{A}$, lanes 7 and 12). In contrast, a hypophosphorylated form of $\mathrm{pRb}$ was visualised when cyclin D1 was degraded (24 h after stimulation with $1 \mu \mathrm{M}$ muristerone $\mathrm{A}$, lanes 5 and 10$)$. Thus, the kinetics of $\mathrm{pRb}$ hyperphosphorylation was in good correlation with the presence of cyclin D1 protein. On the contrary, the expression pattern of p107 and p130 (Figure 9B,C) was not modified after cyclin D1 induction. In vivo, pRb is specifically phosphorylated at various sites by distinct cyclin/CDK complexes. ${ }^{29}$ We used an antibody that recognises CDK4/6 targets, i.e. serine 807 and serine 811 residues to monitor cyclin D1/CDK4/6 activity

A.

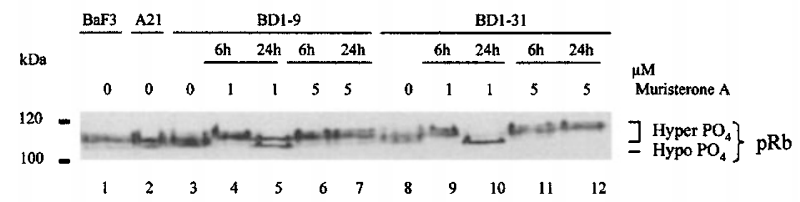

B.

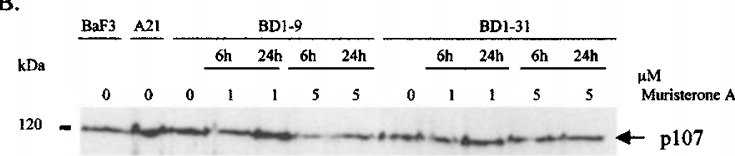

C.

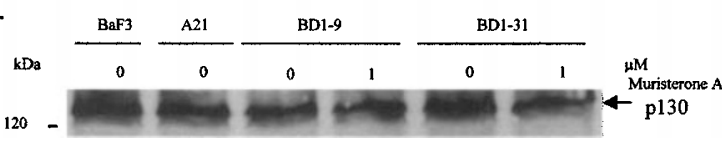

Figure 9 Western blot analysis of the phosphorylation status of $p R b$ and of pocket proteins. Whole cell extracts were prepared as before from cells treated or not with 1 or $5 \mu \mathrm{M}$ muristerone $\mathrm{A}$ and harvested 6 or $24 \mathrm{~h}$ later. The pocket proteins (pRb, p107 and p130) were detected after separation of $100 \mu \mathrm{g}$ of proteins by SDS-PAGE $(8 \%)$ followed by immunoblotting with the respective antibodies. A21 are BD1-A21 cells 
in BaF3 and derivatives after cyclin D1 induction. As depicted in Figure 10, accumulation of $\mathrm{pRb}$ phosphorylated on Ser $^{807 / 811}$ at $6 \mathrm{~h}$ coincided with the hyperphosphorylation of $\mathrm{pRb}$ (Figure 9A) and induction of cyclin D1 expression. The basal level of phosphorylated Ser $r^{807 / 811} \mathrm{pRb}$ present both in BaF3 and in non-stimulated BD1-9 and BD1-31 cells likely represents the activity of cyclin D2/D3/CDK4/6 complexes. The finding that expression of cyclin D1 parallels the CDK4/6 activity strongly suggests that active cyclin D1/CDK4/6 enzymatic complexes mediate hyperphosphorylation of $\mathrm{pRb}$.

\section{Analysis of p53, p21 and Bax protein status in cyclin D1-mediated apoptosis}

Cell response to apoptotic stimuli often implicates the p53signalling pathway. Indeed, p53 promotes both cell-cycle arrest through induction of the CDK inhibitor (CKI) p21 and apoptosis through induction of the Bax pro-apoptotic protein. $^{30,31}$ As reported in Figure 11, the expression of cyclin D1 had no effect on p53 level nor on its targets p21 and
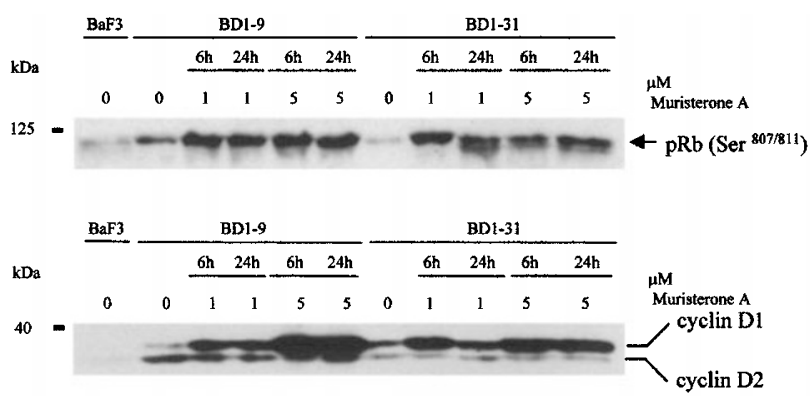

Figure 10 Western blot analysis of phosphorylated pRb protein on Ser 807/ 811 residues. Extracts were prepared as in the legend of Figure $9,100 \mu \mathrm{g}$ of proteins were separated on $8 \%$ SDS-PAGE and analyzed sequentially with anti-phospho-pRb antibody specific for CDK4/6 phosphorylation (top) and anti-cyclin D1 antibody (bottom)
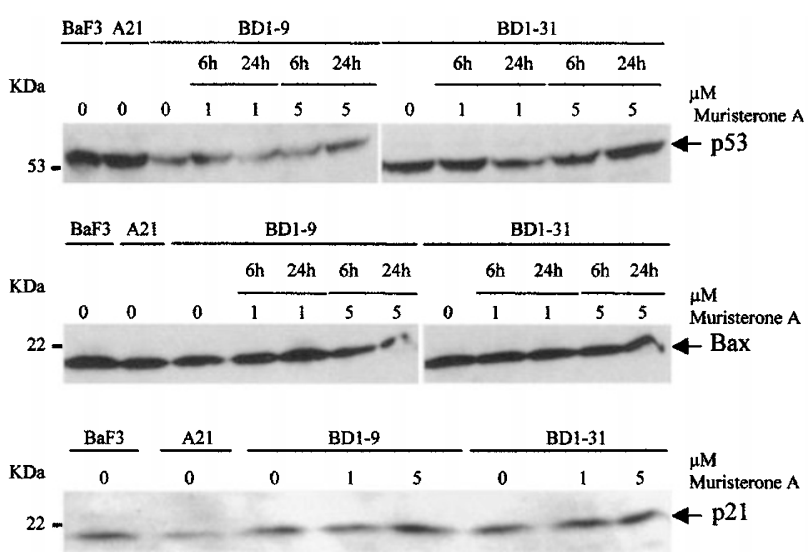

Figure 11 Western blot analysis of proteins of the $p 53$ transduction pathway. Whole cell extracts (for anti-p53 and anti-Bax antibodies) or nuclear extracts (for anti-p21 antibody) were prepared from BaF3, BD1 -9, BD1-31 and BD1A21 (A21) cells and $50 \mu \mathrm{g}$ of proteins were separated on $12 \%$ SDS-PAGE. After transfer onto Immobilon membranes, immunoblots were incubated with indicated antibodies then revealed with ECL chemiluminescence
Bax. Thus, the p53 transduction pathway is probably not associated with cyclin D1-mediated cell death.

\section{Discussion}

As previously reported for lymphoid cells, ${ }^{20} \mathrm{BaF} 3$ cells do not express cyclin D1. We investigated the direct effects of cyclin D1 on cell proliferation by inducing its expression in these cells. Like others using various cell lines, ${ }^{15,32}$ we have been unable to obtain stable transfected BaF3-derived cell lines expressing high levels of cyclin D1 (the cyclin D1 cDNA was under the control of the CMV promoter). Retrospectively, considering our results, induction of cell death by high levels of cyclin D1 provides an explanation for the low efficiency with which stable cyclin D1-expressing cells were generated. The inducible TetOn/TetOff system successfully used by Resnitzky and colleagues in fibroblasts ${ }^{16}$ was leaky in our hands; finally, we used the ecdysone-derived inducible system $^{26}$ to analyse the effects of cyclin D1 expression in BaF3. Our results demonstrate that the system is efficient, since stable transfected cells exhibit a rapid response after hormone treatment, which is time- and dose-dependent and reversible (Figures 1 and 2 ).

If non induced BaF3-derived clones (BD1-9, BD1-31) and $\mathrm{BD} 1-\mathrm{A} 21$ display virtually identical proliferation rates, in the presence of muristerone A, BD1-9 and BD1-31 cells exhibit altered proliferation rates (Figure 3 , Table 1). Over-expression of cyclin D1 induces cell death (Figure 4), characterised as apoptotic (Table 4 and Figures 5 and 6), but a more moderate level of cyclin D1 has no effect on cell viability. Cyclin D1 inhibits rather than stimulates cell proliferation, in agreement with previous findings in mammary cell lines. ${ }^{18,19} \mathrm{~A}$ block of proliferation, likely due to the up regulation of cyclin-dependent kinase inhibitors (CKI) such as $\mathrm{p} 21^{\mathrm{CIP} 1}$ or $\mathrm{p} 27^{\mathrm{KIP} 1}$, has been described for irreversibly growth-arrested cells such as senescent cells $^{33,34}$ or terminally differentiated cells, ${ }^{35,36}$ both types expressing high levels of cyclin D1. The induction of $\mathrm{p} 21^{\mathrm{CIP} 1}$ and $\mathrm{p} 27^{\mathrm{KIP} 1}$ directly or indirectly under the control of cyclin D1 has also been demonstrated in an experimental model of cyclin D1 ectopic expression in several cell types such as mammary epithelial cells, ${ }^{19}$ human gliomas and rodent fibroblasts. ${ }^{37,38} \mathrm{p} 27^{\mathrm{KIP} 1}$ is not expressed in growing $\mathrm{BaF} 3$ and in $\mathrm{BD} 1$ sub-clones with or without treatment by muristerone $A$ (data not shown) and the level of $\mathrm{p} 21^{\mathrm{CIP} 1}$ present in BaF3 and derivatives is not modified after cyclin D1 induction (Figure 11). Thus, the lengthening of cell cycle phase duration is not mediated by the cyclin $\mathrm{D} 1 / \mathrm{CDK}$ inhibitors such as $\mathrm{p} 21^{\mathrm{CIP} 1}$ or $\mathrm{p} 27^{\mathrm{KIP} 1}$. It has been suggested that cyclin D1 could tie up the PCNA protein inducing a lengthening of S-phase in epithelial cells. ${ }^{18} \mathrm{We}$ have not addressed this point but over-expressed cyclin D1 likely alters the duration of all cycle phases, presumably by others mechanism than simple PCNA deficiency. The effects of stable expression of an exogenous cyclin D1 cDNA in BaF3 cells might be due not only to the level of cyclin D1 produced after hormone stimulation but also to the level of protein partners such as other cyclins or cyclindependent kinases. But as reported here, accumulation of cyclin D1 was not associated with major changes in 
expression levels of cyclins D2, D3, and their partners CDK4, CDK6 or cyclin A, cyclin E and CDK2, all involved in regulation of progression through $\mathrm{G} 1$ or in the G1-to-Sphase transition (Figure 8). We propose that inhibition of proliferation is an indirect effect caused by triggering of the apoptotic machinery.

In fact, in BaF3-derived lymphoid cells, cyclin D1 overexpression, sustained expression of cyclin D1 or induction of cyclin D1 in growth factor-deprived cells or in anticancer drug-exposed cells, always induces apoptosis. It has been previously shown that over-expression of human cyclin D1 in a mouse epithelial cell line ${ }^{19}$ or in a human epithelial cell line $^{18}$ has the same apoptotic effects. These results indicate that the observed induction of apoptosis is not the reflect of the expression of a human gene in a murine cell. The high degree of identity between the human and the murine proteins makes this also unlikely.

Although the role of cyclin D1 in cell proliferation is well established, its function in promoting apoptosis is not completely understood. Hyperphosphorylated forms of $\mathrm{pRb}$ are present in fibroblasts conditionally expressing cyclin D1. ${ }^{39}$ In the present study, when no changes for p107 and p130 proteins were detected, the expression of cyclin D1 leads to immediate appearance of hyperphosphorylated $\mathrm{pRb}$. Indeed, we found a strict concordance between cyclin D1 level, hyperphosphorylated status of $\mathrm{pRb}$ and presence of phosphorylated Ser 807 and Ser 811 residues, implying that cyclin D1/CDK4/6 complexes cause pRb phosphorylation on CDK4/6 specific sites (Figure 10). This demonstrates that the exogenous cyclin D1 is functional in $\mathrm{BaF} 3$ cells and that the resulting reduced proliferation rate and apoptosis are not due to inhibition of cyclin D1-associated kinase activity or titration of cell cycle promoting factors but rather to activation of the catalytic complex. Kranenburg and colleagues reported previously that the induction of cyclin D1-dependent kinase activity was a prerequisite for the induction of apoptosis. ${ }^{40}$ Our results are in good agreement with this statement.

In a fibroblastic cell line, the ectopic expression of cyclin D1 is sufficient to provoke apoptosis during serum starvation. ${ }^{41}$ Cells deprived of growth factor cease proliferation and do not express cyclin D1. The authors suggest that the concomitant phosphorylation of $\mathrm{pRb}$ in the absence of growth signals deregulates the $p R b / E 2 F$ control. Such a deregulation of $\mathrm{pRb} / \mathrm{E} 2 \mathrm{~F}$ could occur in cyclin D1-over-expressing lymphoid cells and faster or with a higher magnitude in cells depleted in IL-3. However, we also observed that cyclin D1 enhances the effects of etoposide on cell apoptosis in BaF3 derivatives (Figure 7). Etoposide is a DNA damaging agent which causes direct DNA strand breaks and does not interfere with the growth factor signalling pathway. Therefore, the hypothesis of a conflict between agonistic signals, i.e. absence of growth factor and hyperphosphorylation of $\mathrm{pRb}$ or sustained expression of cyclin D1 all along the cell cycle is inadequate. It was reported that cyclin D1 enhanced radiosensitivity of MCF-7 breast tumour cells via p53 and p21 induction and a faster progression through the G2/Mphase of the cell cycle. ${ }^{42} \mathrm{~A}$ role for cyclin D1 in p53mediated apoptosis following UVC irradiation of glioblasto- ma cells has also been described. ${ }^{43}$ We analyzed the level of p53 and p21 proteins and found no induction after cyclin D1 expression (Figure 11). We also tested the protein level of Bax, a pro-apoptotic member of the Bcl-2 family and a target of p53 apoptotic signalling pathway ${ }^{30,31}$ and found a constant level of Bax protein in all culture conditions. Again, in agreement with the data of Kranenburg et al., ${ }^{40}$ the apoptotic pathway elicited by cyclin D1 induction is p53independent.

Overexpression of cyclin D1 could eliminate $p R b$ function through its functional inactivation. The induction of cyclin D1 results in the hyperphosphorylation of $\mathrm{pRb}$ and in turn possibly, in the release of free E2F-1. One can suggest that either too numerous free E2F-1 molecules or E2F-1 molecules present at the wrong time during the cell cycle do not act as transcription factors of the S-phase genes but, directly or in combination with other proteins, activate genes necessary for apoptosis. In fact, high levels of free E2F-1 have been shown to inhibit proliferation and to promote apoptosis particularly in lymphocytes. ${ }^{44}$ As originally described by $\mathrm{Wu}$ and Levine, ${ }^{45}$ a deregulated expression of E2F-1 triggers apoptosis through the stabilisation of p53. ${ }^{46,47}$ But other studies have documented the apoptotic activity of E2F-1 in a p53-independent fashion. ${ }^{48-50}$ Interestingly, E2F-1 can cooperate with DNA damaging agents to enhance p53-independent apoptosis. ${ }^{51}$ These arguments strongly suggest the participation of E2F-1 molecules in the cyclin D1-mediated apoptosis. The status of E2F-1 molecules as well as the characterisation of E2F-1-associated molecules in cyclin D1-expressing cells need to be studied further.

In conclusion, regardless of the underlying mechanism(s), in lymphoid cells, stable expression of cyclin D1 inhibits proliferation and enhances apoptosis after growth factor deprivation or anticancer drug treatment. Cyclin D1 is probably not oncogenic per se in B-lymphocytes but rather alters their sensitivity towards apoptotic signals.

\section{Materials and Methods}

\section{BaF3 cell culture and generation of cyclin D1-expressing BaF3 clones}

The murine IL-3-dependent pro- $\mathrm{B}$ cell line $\mathrm{BaF}^{25}$ was cultured in RPMI 1640 containing 10\% foetal calf serum (FCS) and 5\% WEHI-3B cells conditioned medium (CM) as source of IL-3; cells were maintained at $37^{\circ} \mathrm{C}$ in a humid atmosphere, at a density of $5 \times 10^{3}$ to $5 \times 10^{5}$ cells per ml. For IL-3 deprivation, cells were washed twice and then cultured in RPMI plus 10\% FCS. For induction of apoptosis, cells were treated with $40 \mu \mathrm{g} / \mathrm{ml}$ etoposide (Sigma) and harvested at different time intervals. To generate D1-expressing cells, we used the ecdysone-inducible system described by No et al. ${ }^{26}$ and a two-step procedure as suggested by the supplier (Invitrogen, Groningen, The Netherlands). After the first transfection with the regulatory plasmid $\mathrm{pVgRXR}$, selection with zeocin $(500 \mu \mathrm{g} / \mathrm{ml})$ and cloning by limiting dilution, 12 clones were recovered. All clones were then transfected with the expression plasmid pIND containing the complete cDNA of human cyclin D1 (9), pIND-D1, before the selection in G418 $(250 \mu \mathrm{g} /$ $\mathrm{ml}$ ) and cloning by limiting dilution. Three clones, thereafter referred as BD1-9, BD1-31 and BD1-A21 were presented in this study. 
Transfections of BaF3 cells or BaF3 subclones were achieved by electroporation ( $250 \mathrm{~V}, 260 \mu \mathrm{F}$, Gene Pulser II, Bio-Rad).

\section{Cell proliferation analysis}

Equivalent number of cells was seeded $\left(5 \times 10^{3}\right.$ or $5 \times 10^{4}$ per ml) into 24-well or 6-well plates at least in triplicate. During the culture period, cells were refed with fresh medium every 2 days. Viable cells, excluding Trypan blue were counted in a haemocytometer at different time intervals. Doubling times of parental BaF3 and cyclin D1expressing cells were calculated from initial exponential phase $(24 \mathrm{~h})$ of the proliferation curve. For comparison of cell viability values, statistical analysis was carried out by the Student $t$-test. $P<0.01$ was considered as significant.

\section{Cell cycle analysis}

For each culture condition, $5 \times 10^{5}$ cells were washed twice in phosphate-buffered saline (PBS), pelleted and suspended in ice-cold ethanol $(70 \%$ in PBS). Fixed cells were then centrifuged and suspended in PBS containing $100 \mu \mathrm{g} / \mathrm{ml}$ RNase A (Roche Molecular Biochemicals) and $20 \mu \mathrm{g} / \mathrm{ml}$ propidium iodide (PI, Sigma) for $30 \mathrm{~min}$ at $37^{\circ} \mathrm{C}$. Cells (10000 events per condition) were analyzed with a FACScalibur (Becton-Dickinson) and data with the CellQuest 1.2.2 and the ModFit LT 1.01 softwares (Becton-Dickinson).

\section{DAPI-staining and microscopic examination}

BaF3 cells and derivatives $\left(5 \times 10^{4}\right.$ cells) treated or not with $5 \mu \mathrm{M}$ muristerone $A$ for 2 days, were cytospun on poly-L-lysine-coated glass slides (Menzel-Glaser) and then fixed in a mixture of ethanol/ chloroform/acetic acid (6/3/1). After drying, $100 \mu \mathrm{l}$ of $4^{\prime}, 6^{\prime}$-diamidino2-phenylindole (DAPI) solution $(100 \mu \mathrm{g} / \mathrm{ml})$ were added and slides incubated for $30 \mathrm{~min}$ at room temperature. After two washes in water, slides were mounted with Mowiol (Calbiochem) and analyzed with an epifluorescence microscope equipped with a DAPI filter (Leica).

\section{Western blot analysis}

Whole cell extracts were obtained from $5 \times 10^{6}$ cells lysed in a buffer containing Tris $20 \mathrm{mM} \mathrm{pH}$ 8.0, NaCl $150 \mathrm{mM}$, Triton X-100 1\%, EDTA $5 \mathrm{mM}, \mathrm{Na}$ orthovanadate $1 \mathrm{mM}, \mathrm{NaF} 10 \mathrm{mM}$, leupeptin $10 \mu \mathrm{g} / \mathrm{ml}$, aprotinin $10 \mu \mathrm{g} / \mathrm{ml}$, PMSF $100 \mu \mathrm{g} / \mathrm{ml}$ for $30 \mathrm{~min}$ at $4^{\circ} \mathrm{C}$. Lysates were centrifuged at 12000 r.p.m. for $15 \mathrm{~min}$ at $4^{\circ} \mathrm{C}$ and supernatants collected. Protein concentration was determined with the Bio-Rad assay. Nuclear extracts were obtained from $10^{7}$ cells incubated $5 \mathrm{~min}$ on ice in buffer A (HEPES $20 \mathrm{mM} \mathrm{pH} \mathrm{7.9,} \mathrm{KCl} 10 \mathrm{mM}, \mathrm{NP}-400.2 \%$, glycerol $10 \%$, DTT $1 \mathrm{mM}$ and the same protease inhibitor cocktail as before). Cells were then centrifuged at $12000 \times g$ for 2 min at $4^{\circ} \mathrm{C}$ and the pellet (of nuclei) was then incubated $30 \mathrm{~min}$ on ice in buffer $\mathrm{B}$ (HEPES $20 \mathrm{mM}$ pH 7.9, KCl $10 \mathrm{mM}, \mathrm{NaCl} 400 \mathrm{mM}$, glycerol 20\%, EDTA $1 \mathrm{mM}$, DTT $1 \mathrm{mM}$ and the protease inhibitor cocktail). Samples were centrifuged at $12000 \times g$ for $2 \mathrm{~min}$ at $4^{\circ} \mathrm{C}$ and proteins from supernatants assayed with the BioRad assay. Fifty to one hundred $\mu \mathrm{g}$ of protein extracts were separated by 8 or $12 \%$ SDS-PAGE and transferred onto Immobilon P membrane (Millipore). Equal loading of protein sample was visually confirmed by naphtol blue black staining. Membranes were first blocked in PBS containing 0.2\% Tween-20 and $5 \%$ non fat dry milk (PBS-T-M) for $1 \mathrm{~h}$ at room temperature, then washed three times with PBS-T. Blots were incubated with the primary antibody diluted in PBS-T-M for $2 \mathrm{~h}$ at room temperature, washed, incubated with the secondary antibody for $1 \mathrm{~h}$ at room temperature.
After washes, blots were revealed by the ECL chemiluminescence kit (Amersham Pharmacia Biotech.) and autoradiographied.

\section{Antibodies}

The following antibodies were used for Western blot analysis: from Santa Cruz Biotechnology Inc., rabbit polyclonal antibodies anti-cyclin D1 (sc-718), anti-cyclin D3 (sc-182), anti-cyclin A (sc-751), anti-cyclin E (sc-481), anti-CDK4 (sc-260), anti-CDK6 (sc-177), anti-p21 (sc397), anti-p27 (sc-528), anti-p130 (sc-317), anti-Bax (sc-493), a mouse monoclonal antibody anti-CDK2 (sc-6248); from Oncogene Research, mouse monoclonal antibodies anti-p53 (Ab-1 and Ab-3) and from Pharmingen, mouse monoclonal antibodies anti-cyclin D2 (G13243), anti-pRb (14001A). The polyclonal anti-phospho-Rb (Ser807/ Ser811) was purchased from New England Biolabs (no 9308S). As secondary antibodies, we used a donkey peroxidase-linked anti-rabbit Ig and a rabbit peroxidase-linked anti-mouse Ig (Amersham Pharmacia Biotech.).

\section{Inhibition of 265 proteasome}

BD1-9 and BD1-31 cells were seeded at $5 \times 10^{5}$ cells $/ \mathrm{ml}$ in medium containing $1 \mu \mathrm{M}$ muristerone $\mathrm{A}$. Six $\mathrm{h}$ later, cells were treated with $25 \mu \mathrm{M}$ LLnL (N-acetyl-leucinyl-leucinyl-norleucinal, Sigma) for $18 \mathrm{~h}$, then harvested. Cell extracts were analyzed by Western blotting with anti-cyclin D1 antibody as mentioned before.

\section{Acknowledgements}

The authors thank Dr. Gordon Peters (ICRF, London, UK) for the gift of the human cyclin D1 cDNA, Dr. Fabrice Gouilleux (ICGM, INSERM U363, Paris, France) for the BaF3 cell line and for his precious support. We also thank Dr. Stéphane Allouche (Laboratoire de Biochimie, CHU Côte de Nacre, Caen, France), Dr. Luisa Dandolo (ICGM, INSERM U257, Paris, France), Dr. Vernice Jackson-Lewis and Dr. Christelle Guégan (Department of Neurology, Columbia University, New York, USA) for critically reading the manuscript and Mrs. Anne Barbaras for technical help. The work was financially supported by the Fondation pour la Recherche Médicale (Grant no 40001291-02 to B Sola), by the Ligue Nationale contre le Cancer - Comité du Calvados (Grants 1998 and 1999 to B Sola). F Duguesne and G Roué are fellows of the Ligue Nationale contre le Cancer - Comité du Calvados and Comité de l'Orne, respectively.

\section{References}

1. Sherr CJ (1994) G1 phase progression: Cycling on cue. Cell 79: 551-555

2. Weinberg RA (1995) The retinoblastoma protein and cell cycle control. Cell 81: $323-330$

3. Sherr CJ (1996) Cancer cell cycles. Science 274: 1672-1677

4. Inaba T, Matsushime H, Valentine M, Roussel MF, Sherr CJ and Look AT (1992) Genomic organization, chromosomal localization, and independent expression of human cyclin D genes. Genomics 13: $565-574$

5. Bartkova J, Lukas J, Strauss M and Bartek J (1994) The PRAD-1/cyclin D1 oncogene product accumulates aberrantly in a subset of colorectal carcinomas. Int. J. Cancer 58: 568-573

6. Lammie GA, Fantl V, Smith R, Schuuring E, Brookes S, Michalides R, Dickson C, Arnold A and Peters G (1991) D11S287, a putative oncogene on chromosome $11 \mathrm{q} 13$, is amplified and expressed in squamous cell and mammary carcinomas and linked to BCL-1. Oncogene 6: 439-444 
7. Michalides R, van Veelen N, Hart A, Loftus B, Wientjens E and Balm A (1995) Overexpression of cyclin D1 correlates with recurrence in a group of forty-seven operable squamous cell carcinomas of the head and the neck. Cancer Res. 55 975-978

8. SchuuringE,VerhoevenE,MooiWJandMichalidesRJAM(1992)Identificationand cloning of two overexpressed genes U21B31/PRAD1 and EMS1, within the amplifiedchromosome11q13regioninhumancarcinomas. Oncogene7:355-361

9. Motokura T, Bloom T, Goo Kim H, Jüppner H, Ruderman JV, Kronenberg HM and Arnold A (1991) A novel cyclin encoded by a bcl1-linked candidate oncogene. Nature 350: $512-515$

10. Jiang W, Kahn SM, Tomita N, Zhang YJ, Lu SH and Weinstein IB (1992) Amplification and expression of the human cyclin $\mathrm{D}$ gene in esophageal cancer. Cancer Res. 52: 2980-2983

11. Jenkins TD, Mueller A, Odze R, Shahsafaie A, Zukerberg LR, KentR, Stoner GD and Rustgi AK (1999) Cyclin D1 overexpression combined with Nnitrosomethylbenzylamine increases dysplasia and cellular proliferation in murine esophageal squamous epithelium. Oncogene 18: 59-66

12. Wang TC, Cardiff RD, Zukerberg L, Lees E, Arnold A and Schmidt EV (1994) Mammary hyperplasia and carcinoma in MMTY-cyclin D1 transgenic mice. Nature 369: 669-671

13. Bodrug SE, Warner BJ, Bath ML, Lindeman GJ, Harris AW and Adams JM (1994) Cyclin D1 transgene impedes lymphocyte maturation and collaborates in lymphomagenesis with the myc gene. EMBO J. 13: 2124-2130

14. Jiang W, Kahn SM, Zhou P, Zhang YJ, Cacace AM, Infance AS, Doi S, Santella RMand Weinstein IB (1993) Overexpression of cyclin D1 in rat fibroblasts causes abnormalities in growth control, cell cycle progression and gene expression. Oncogene 8: 3447-3457

15. Quelle DE, Ashmun RA, Shurtleff SA, Kato JY, Bar-Sagi D, Roussel MF and Sherr CJ (1993) Overexpression of mouse D-type cyclins accelerates G1 phase in rodent fibroblasts. Genes Dev. 7: 1559-1571

16. Resnitzky D, Gossen M, Bujard H and Reed SI (1994) Acceleration of the G1/S phase transition by expression of cyclins D1 and $E$ with an inducible system. Mol. Cell. Biol. 14: 1669-1679

17. Zwijsen RML, Klompmaker R, Wientjens EBHGM, Kristel PMP, van der Burg B and Michalides RJAM (1996) Cyclin D1 triggers autonomous growth of breast cancer cells by governing cell cycle exit. Mol. Cell. Biol. 16: 2554-2560

18. Han EKH, Sgambato A, Jiang W, Zhang YU, Santella RM, Doki Y, Cacace AM, Schieren I and Weinstein IB (1995) Stable overexpression of cyclin D1 in a human mammary epithelial cell line prolongs the S-phase and inhibits growth Oncogene 10: 953-961

19. Han EKH, Begemann M, Sgambato A, Soh JW, Doki Y, Xing WQ, Liu W and Weinstein IB (1996) Increased expression of cyclin D1 in a murine mammary epithelial cell line induces $\mathrm{p} 27^{\mathrm{KIP} 1}$, inhibits growth, and enhances apoptosis. Cell Growth Differ. 7: 699-710

20. Ando K, Ajchenbaum-Cymbalista F and Grifffin JD (1993) Regulation of G1/S transition by cyclins D2 and D3 in hematopoïetic cells. Proc. Natl. Acad. Sci. USA 90: 9571-9575.

21. Palmero I, Holder A, Sinclair AJ, Dickson C and Peters G (1993) Cyclins D1 and D2 are differentially expressed in human B-lymphoid cell lines. Oncogene 8 : $1049-1054$

22. de Boer CJ, Schuuring E, Dreef E, Peters G, Bartek J, Kluin PM and van Krieken JHJM (1995) Cyclin D1 protein analysis in the diagnosis of mantle cell lymphoma. Blood 86: 2715-2723

23. Weisenburger DD and Armitage JO (1996) Mantle cell lymphoma - An entity comes of age. Blood 87: 4483-4494

24. Cuneo A, Bigoni R, Negrini M, Bullrich F, Veronese ML, Roberti MG, Bardi A, Rigolin GM, Cavazzini P, Croce CM and Castoldi G (1997) Cytogenetic and interphase cytogenetic characterization of atypical chronic lymphocytic leukemia carrying BCL1 translocation. Cancer Res. 57: 1144-1150

25. Palacios R and Steimetz M (1985) IL-3-dependent mouse clones that express B220 surface antigen, contain Ig genes in germ-line configuration, and generate $B$ lymphocytes in vivo. Cell 41: 727-734

26. No D, Yao TP and Evans RM (1996) Ecdysone-inducible gene expression in mammalian cells and transgenic mice. Proc. Natl. Acad. Sci. USA 93: $3346-$ 3351

27. Diehl JA, Zindy F and Sherr CJ (1997) Inhibition of cyclin D1 phosphorylation on threonine-286 prevents its rapid degradation via the ubiquitin-proteasome pathway. Genes Dev. 11: 957-972
28. Rodriguez-Tarduchy G, Collins M and Lopez-Rivas A (1990) Regulation of apoptosis in interleukin-3-dependent hemopoietic cells by interleukin-3 and calcium ionophores. EMBO J. 9: 2997-3002

29. Zarkowska $T$ and Mittnacht S (1997) Differential phosphorylation of the retinoblastoma protein by G1/S cyclin-dependent kinases. J. Biol. Chem. 272: $12738-12746$

30. Levine AJ (1997) p53, the cellular gatekeeper for growth and division. Cell 88 : 323-331

31. Evan G and Littlewood T (1998) A matter of life and death. Science 281: 13171322

32. Atadja P, Wong H, Veillete C and Riabowol K (1995) Overexpression of cyclin D1 blocks proliferation of normal diploid fibroblasts. Exp. Cell. Res. 217: 205-216

33. Dulic V, Drullinger LF, Lees E, Reed SI and Stein GH (1993) Altered regulation of G1 cyclins in senescent human diploid fibroblasts: Accumulation of inactive cyclin E-Cdk2 and cyclin D1-cdk2 complexes. Proc. Natl. Acad. Sci. USA 90: $11034-11038$

34. Lucibello FC, Sewing A, Brüsselbach S, Bürger C and Müller R (1993) Deregulation of cyclins D1 and E and suppression of cdk2 and cdk4 in senescent human fibroblasts. J. Cell Sci. 105: 123-133

35. van Grunsven LA, Thomas A, Urdiales JL, Machenaud S, Choler P, Durand I and Rudkin BB (1996) Nerve growth factor-induced accumulation of PC12 cells expressing cyclin D1: evidence for a G1 phase block. Oncogene 12: 855-862

36. Yan GZ and Ziff EB (1995) NGF regulates the PC12 cell cycle machinery trough specific inhibition of the cdk kinases and induction of cyclin D1. J. Neurosci. 15: $6200-6212$

37. Hijama H, lavarone A, LaBaer J and Reeves SA (1997) Regulated ectopic expression of cyclin D1 induces transcriptional activation of the cdk inhibitor p21 without altering cell cycle progression. Oncogene 14: 2533-2542

38. Imoto M, Doki Y, Jiang W, Han EKH and Weinstein IB (1997) Effects of cyclin D1 overexpression on G1 progression-related events. Exp. Cell. Res. 236: 173180

39. Resnitzky D and Reed SI (1995) Different roles for cyclins D1 and E in regulation of the G1-to-S transition. Mol. Cell. Biol. 15: 3463-3469

40. Kranenburg O, van der Eb AJ and Zantema A (1996) Cyclin D1 is an essential mediator of apoptotic neuronal cell death. EMBO J. 15: 46-54

41. Sofer-Levi Y and Resnitzky D (1996) Apoptosis induced by ectopic expression of cyclin D1 but not cyclin E. Oncogene 13: 2431-2437

42. Coco Martin JM, Balkenende A, Verschoor T, Lallemand F and Michalides $R$ (1999) Cyclin D1 overexpression enhances radiation-induced apoptosis and radiosensitivity in a breast tumor cell line. Cancer Res. 59: 1134-1140

43. Hiyama $\mathrm{H}$ and Reeves SA (1999) Role for cyclin D1 in UVC-induced and p53mediated apoptosis. Cell Death Differ. 6: 565-569

44. Johnson DG, Ohtani K and Nevins JR (1994) Autoregulatory control of E2F1 expression in response to positive and negative regulators of cell cycle progression. Genes Dev. 8: 1514-1525

45. Wu Xand Levine AJ (1994) p53 and E2F-1 cooperate to mediate apoptosis. Proc. Natl. Acad. Sci. USA 91: 3602-3606

46. KowalikTF, DeGregori J, Leone G, Jakoi L and Nevins JR (1998) E2F-1-specific induction of apoptosis and p53 accumulation, which is blocked by Mdm2. Cell Growth Differ. 9: 113-118

47. Bates S, Phillips AC, Clarke PA, Stott F, Peters G, Ludwig RL and Vousden KH (1998) p14 ${ }^{A R F}$ links the tumour suppressors RB and p53. Nature 395: 124-125

48. Holmberg C, Helin K, Sehested M and Karlström O (1998) E2F-1-induced p53independent apoptosis in transgenic mice. Oncogene 17: 143-155

49. Pierce AM, Gimenez-Conti IB, Schneider-Broussard R, Martinez LA, Conti CJ and Johnson DG (1998) Increased E2F-1 activity induces skin tumors in mice heterozygous and nullizygous for p53. Proc. Natl. Acad. Sci. USA 95: 88588863

50. Phillips AC, Ernst MK, Bates S, Rice NR and Vousden KH (1999) E2F-1 potentiates cell death by blocking antiapoptotic signalling pathways. Mol. Cell 4 : $771-781$

51. Nip J, Strom DK, Fee BE, Zambetti G, Cleveland JL and Hiebert SW (1997)E2F-1 cooperates with topoisomerase II inhibition and DNA damage to selectively augment p53-independent apoptosis. Mol. Cell. Biol. 17: 1049-1056 